\title{
Augmented Reality Untuk Media Promosi Rumah Pada Alang-Alang Contruction Berbasis Android
}

\author{
Jayang Nurdiansyah ${ }^{1}$, Achmad Choiron ${ }^{2}$ \\ 1 jayangnurdiansyah@gmial.com, ${ }^{2}$ choironunitomo@gmail.com
}

Program Studi Teknik Informatika Universitas Dr.Soetomo Surabaya

\begin{abstract}
Augmented reality application for home promotion media on Alang-Alang Construction based on android, designed as a supporting media of house promotion to make it easier to sell house, where usually promote home using ordinary brochure hence from that company can utilize Augmented reality technology on Mobile Phone with Android Operating System in order to lift the company's image and have its own plus value in front of potential customers In this final project will be built applications by utilizing Augmented reality technology as a merger of real objects and virtual in real environment, running in real time interactive, with method of Marker or target which gives to appear 3D object simultaneously. In making this application using Unity as supporting software and using Vuforia SDK as its data management, three-dimensional object created using Autodesk 3ds Max. With the creation of this application, it can help the marketing to attract customers also provide the results of home model presentation in front of prospective customers become more professional, and from the results of making a $3 D$ home drawing, can help customers to better know the design and type of house to be purchased
\end{abstract}

Intisari- Aplikasi Augmented reality untuk media promosi rumah pada alang-alang construction berbasis android, dirancang sebagai media penunjang promosi rumah untuk lebih memudahkan menjual rumah, dimana biasanya mempromosikan rumah menggunakan brosur biasa maka dari itu perusahaan dapat memanfaatkan teknologi Augmented reality pada Mobile Phone dengan Sistem Operasi Android agar dapat mengangkat citra perusahaan dan mempunyai nilai plus tersendiri dihadapan para calon pelanggan Dalam tugas akhir ini akan dibangun aplikasi dengan memanfaatkan teknologi Augmented reality sebagai penggabungan benda-benda nyata dan maya di lingkungan nyata, berjalan secara interaktif dalam waktu nyata (realtime),dengan metode Marker atau target yang disetting untuk memunculkan objek 3D secara bersamaan. Dalam pembuatan aplikasi ini menggunakan Unity sebagai software pendukungnya dan menggunakan Vuforia SDK sebagai management datanya, objeck tiga dimensi yang dibuat dengan menggunakan Autodesk 3ds Max. Dengan dibuatnya Aplikasi ini, maka dapat membantu marketing untuk menarik minat pelanggan juga memberikan hasil presentasi model rumah dihadapan calon pelanggan menjadi lebih profesional, dan dari hasil pembuatan gambar rumah secara 3D, dapat membantu para pelanggan untuk lebih mengetahui desain dan tipe rumah yang akan dibeli.

KataKunci-Augmented reality,Aplikasi Android, 3D, Rumah

\section{PENDAhuluan}

Bisnis properti saat ini semakin menunjukkan perkembangan yang pesat. Hal ini dapat dilihat dari meningkatnya permintaan pasar terhadap bisnis properti. Seiring dengan tingginya permintaan pasar berbanding lurus dengan banyaknya perusahaan yang menawarkan produknya dengan menggunakan berbagai macam cara baik dengan menggunakan bunga kredit yang sangat kecil ataupun melakukan pemasaran melalui media komunikasi baik cetak ataupun elektronik. Saat ini teknologi hasil gabungan teknologi cetak dan komputer dapat diwujudkan dengan teknologi augmented reality. Augmented reality adalah teknologi yang digunakan untuk merealisasikan dunia virtual ke dalam dunia nyata secara realtime dalam bentuk 2 dimensi maupun 3 dimensi[1].

Melalui media promosi yang saat ini masih digunakan tidak jarang calon pembeli masih merasa bingung untuk membayangkan gambaran atau bentuk rumah yang akan dibangun, karena promosi masih menggunakan objek dua dimensi (2D), yang mempunyai sudut pandang terbatas. Sehingga terkadang pembeli harus mendatangi kantor pemasaran untuk mendapatkan informasi ataupun gambaran yang lebih jelas. Perkembangan teknologi yang pesat memungkinkan perusahaan untuk mengembangkan strategi promosi dan pengenalan produk atau jasa mereka dengan teknologi augmented reality yang interaktif. Dengan media promosi yang hanya menggunakan media iklan atau brosur untuk memaparkan jenis produk atau jasa yang ditawarkan oleh perusahaan tersebut, namun dengan biaya yang relatif cukup banyak dan iklan atau brosur 2D yang ditawarkan kurang menarik minat calon pembeli untuk melihat produk tersebut[2].

Teknologi tersebut dapat memberikan animasi model rumah yang dapat membantu klien untuk memilih model rumah yang diharapkan. Dengan memanfaatkan teknologi Augmented reality untuk customer, akan memungkinkan 
untuk lebih mudah memasarkan produk. Misalkan dengan cara memberikan contoh presentasi model rumah menggunakan Augmented reality yang berupa animasi 3 dimensi, bahwa rumah dari perusahaan tersebut dapat memenuhi keinginan para calon pembeli[3].

Berdasarkan permasalahan di atas, maka penelitian dalam tugas akhir ini diambil judul Augmented reality untuk Media Promosi Rumah pada Alang-Alang Construction Berbasis Android. Diharapkan aplikasi ini dapat menampilkan model rumah nampak seperti nyata kepada calon pembeli. Dan juga dapat mempermudah calon pembeli memilih model rumah sesuai yang diharapkan melalui media animasi 3 dimensi [4].

\section{METODOLOGI PENELITIAN}

Metodologi yang digunakan dalam pembuatan skripsi ini adalah metodologi Microsoft Solution Framework (MSF). Microsoft Solutions Framework (MSF) adalah "serangkaian prinsip, model, disiplin, konsep, dan tuntunan untuk membuat solusi IT" yang diciptakan oleh Microsoft. Bisa dibilang MSF adalah sebuah Software Development Life-Cycle (SDLC). Namun MSF tidak hanya dapat diterapkan pada pembuatan aplikasi, selain itu dapat diterapkan pada proyek-proyek IT lain seperti pembuatan infrastruktur dan jaringan. Ini karena MSF tidak hanya mencakup perekayasaan perangkat lunak namun hampir mencakup pembuatan sebuah proyek IT secara keseluruhan[5]. Karena itu lah MSF tidak disebut sebagai sebuah Metodologi (seperti Metodologi Waterfall, Metodologi Spiral, dll) namun diberi nama Framework. MSF ada beberapa tahapan-tahapan sebagai berikut:

Metodologi yang digunakan dalam pembuatan penelitian ini adalah metodologi Microsoft Solution Framework (MSF) dengan tahapan-tahapan sebagai berikut:

\section{A. Envisioning Phase}

Pada tahapan ini penulis melakukan persiapan awal yang meliputi pengumpulan data penentuan dan pembuatan Marker dengan menggunakan aplikasi photoshop dan corel draw, serta pembuatan objek 3D dengan autodesk 3d max 2010. Autodesk 3Ds Max adalah Software untuk pembuatan animasi tiga dimensi. Sejak pertama kali dirilis, 3D Studio Max menjadi pemimpin aplikasi pembangunan animasi tiga dimensi. Sejak versi ke empat, Discreet, produsen 3D Studio Max, berusaha untuk meluaskan area fungsinya sehingga dapat digunakan untuk membuat animasi bagi Web atau film. Pengertian lain3D Studio Max atau biasa dikenal dengan 3D Max adalah suatu software (Perangkat lunak) untuk membuat sebuah grafik vektor 3 dimensi dan animasi.ditulis oleh Autodesk Media \& Entertainment, dulunya dikenal sebagai Discreet and Kinetix. 3D Studio Max dikembangkan dari pendahulunya yaitu 3D Studio for DOS, tetapi untuk platform Win32.

\section{B. Planning Phase}

Pada tahapan ini penulis membuat rancangan awal tentang Augmented reality rumah kantor serta komponen mana saja yang akan digunakan sebagai object 3D. Teknologi Augmented reality merupakan salah satu trobosan yang digunakan pada akhir - akhir ini di dibidang interaksi. Penggunaan teknologi ini akan sangat membantu dalam menyampaikan suatu informasi kepada pengguna. AR merupakan teknologi interaksi yang menggabungkan antara dunia nyata (real world) dan dunia maya (virtual world). Tujuan dalam penggunaan teknologi AR ini adalah menambahkan pengertian dan informasi pada dunia nyata dimana sistem ini mengambil dunia nyata sebagai dasar dan menggabungkan beberapa teknologi dengan menambahkan data kontekstual agar pemahaman seseorang menjadi jelas.

Dalam teknologi AR ada tiga karakteristik yang menjadi dasar diantaranya adalah kombinasi pada dunia nyata dan virtual, interaksi yang berjalan secara realtime, dan karakteristik terakhir adalah bentuk obyek yang berupa model 3 dimensi atau 3D.Bentuk data kontekstual dalam sistem AR ini dapat berupa data lokasi, audio, video ataupun dalam bentuk data model 3D tertentu.

\section{Developing Phase}

Hasil planning phase dilanjutkan ke tahap pengembangan yaitu penulis mulai merancang sistem secara utuh, merancang objek 3 dimensi rumah dan komponen dengan menggunakan Autodesk 3ds Max 2010, melakukan pemrograman pada Augmented reality dengan menggunakan Unity 3D. Software ini merupakan suatu aplikasi yang digunakan untuk mengembangkan game multi platform yang didesain untuk mudah digunakan. Unity itu bagus dan penuh perpaduan dengan aplikasi yang profesional. Editor pada Unity dibuat degan user interface yang sederhana. Editor ini dibuat setelah ribuan jam yang mana telah dihabiskan untuk membuatnya menjadi nomor satu dalam urutan rankking teratas untuk editor game. Grafis pada unity dibuat dengan grafis tingkat tinggi untuk OpenGL dan directX. Unity mendukung semua format file, terutamanya format umum seperti semua format dari art applications. Unity cocok dengan versi 64-bit dan dapat beroperasi pada Mac OS x dan windows dan dapat menghasilkan game untuk Mac, Windows, Wii, iPhone, iPad dan Android.

\section{Stabilizing Phase}

Setelah menyelesaikan semua objek 3 dimensi dan pengkodean, maka dilanjutkan dengan tahapan melakukan pengujian terhadap aplikasi tersebut apakah telah sesuai dengan analisis yang telah dilakukan. Hasil pengujian didokumentasikan.

\section{E. Deployment Phase}

Setelah selesai melakukan pengujian maka penulis melakukan tahapan terakhir yaitu mengimplementasikan aplikasi ke dalam perangkat mobile device. Untuk selanjutnya diinstal di dalamnya. Dan selanjutnya dilakukan uji penerimaan pada Alang-Alang Construction. Alang-Alang Construction, merupakan usaha yang bergerak di bidang konstruksi di Surabaya. Alang-Alang Construction menyediakan jasa arsitek dan konstruksi bangunan rumah, dari tempat kos, rumah tinggal minimalis, kantor, gedung, ruko 
dan berbagai pekerjaan renovasi bangunan dan rumah. AlangAlang Construction memberikan pelayanan all in one dan secara profesional mulai dari rencana desain sampai dengan konstruksi. Alang-Alang Construction memberikan secara optimal mulai dari pelayanan yang praktis, murah (efisien biaya), hemat waktu dan mengkombinasikan aspek fungsional dan faktor estetika. Alang-alang Construction terletak di Taman Klampis Anom blok G no.47, Surabaya, Provinsi Jawa Timur.

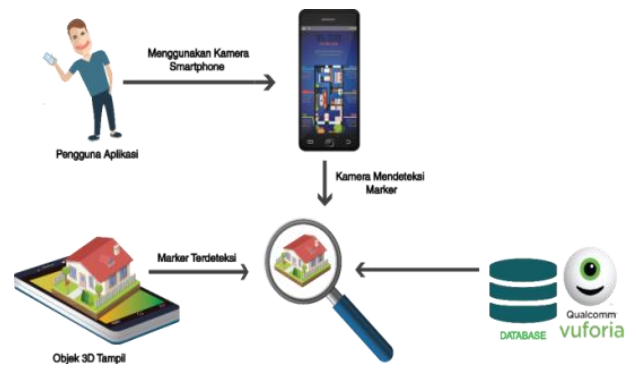

Gambar1 Deskripsi Sistem

Gambaran sistem aplikasi dapat dilihat pada Gambar 1, dimana pengguna aplikasi mengarahkan kamera smartphone kearah gambar Marker, kemudian dari gambar yang dihasilkan dari kamera sistem melakukan proses untuk identifikasi gambar Marker yang sudah diatur di database vuforia setelah proses pengidentifikasian maka sistem akan melakukan proses render objek 3D yang digunakan dalam aplikasi, pengguna bisa melihat objek 3D yang tampil di layar smartphone.

Gambar 2 merupakan algoritma proses jalankan aplikasi adalah runtunan proses dimana pengguna menjalankan aplikasi hingga selesai.

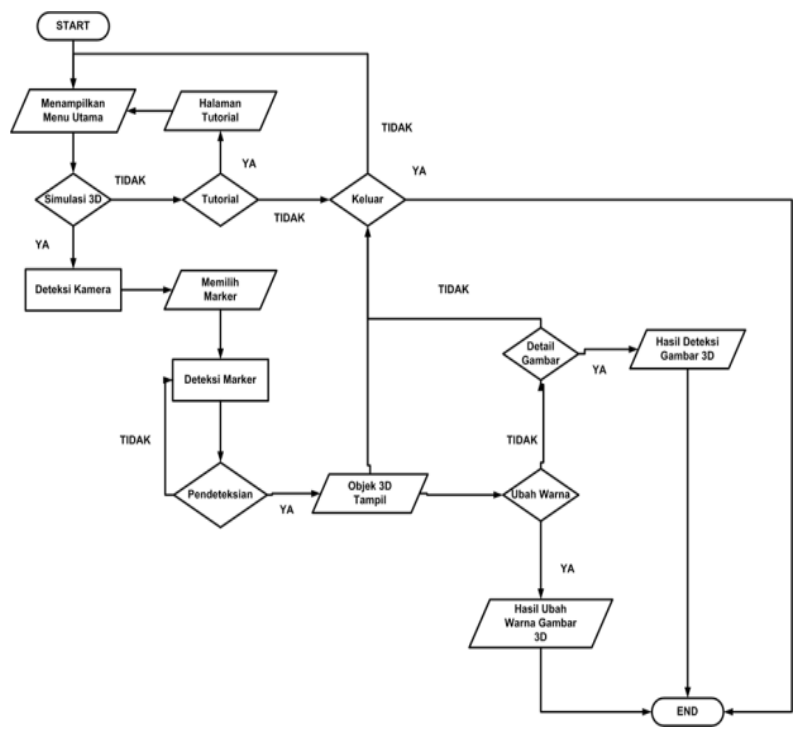

Gambar 2 Algoritma Proses

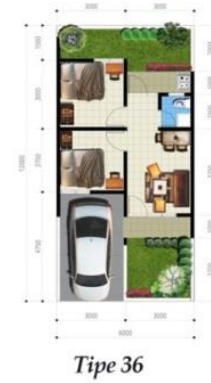

Gambar 3 Marker Tipe 36

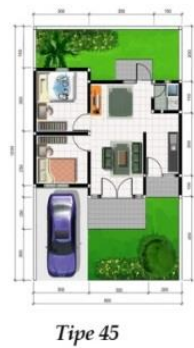

Gambar 4 Marker Tipe 45

Pada Gambar 3 merupakan Marker atau Image Target yang dibutuhkan untuk menampilkan objek rumah 3D yang mempunyai tipe 45 pada aplikasi AREstate.

Tipe 54

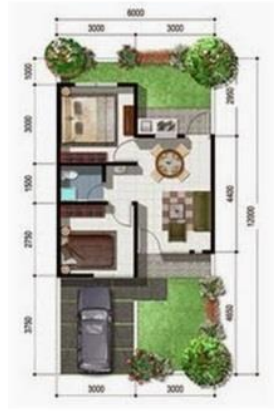

Lantai 1

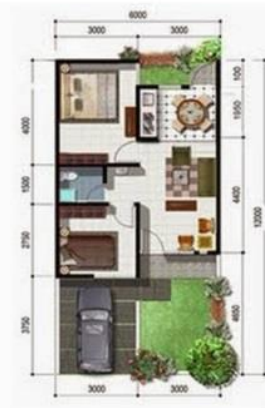

Lantai 2
Gambar 5 Marker Tipe 54

Pada Gambar 5 merupakan Marker atau Image Target yang dibutuhkan untuk menampilkan objek rumah 3D yang mempunyai tipe 54 pada aplikasi AREstate. 


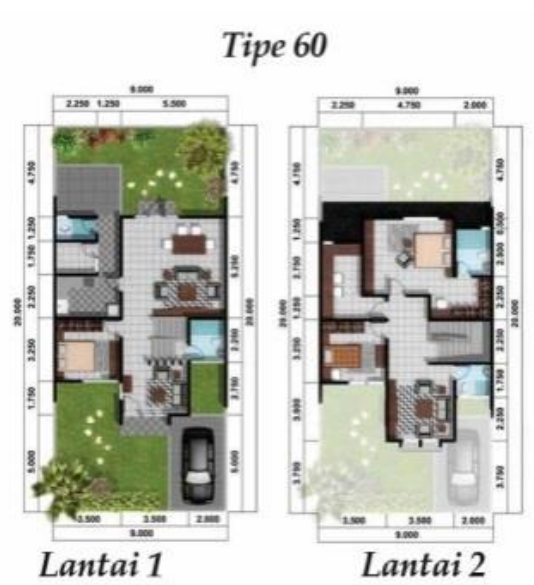

Gambar 6 Marker Tipe 60

Pada Gambar 6 merupakan Marker atau Image Target yang dibutuhkan untuk menampilkan objek rumah 3D yang mempunyai tipe 60 pada aplikasi AREstate.

\section{III.HASIL DAN PEMBAHASAN}

Tahap test case ini bertujuan untuk menunjukkan fungsi perangkat lunak dan tentang cara bekerjanya. Dan melihat penerapan kode program telah berjalan sesuai rancangan yang telah dibuat. Berikut beberapa testing yang dilakukan pada aplikasi.

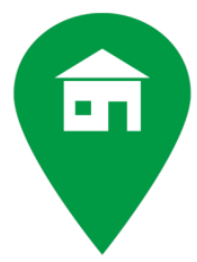

Gambar 7 Splash Screen Aplikasi AREstate

Pada Gambar 7 merupakan tampilan splash screen adalah sebuah tampilan yang pertama kali dilihat oleh pengguna saat pengguna membuka aplikasi.

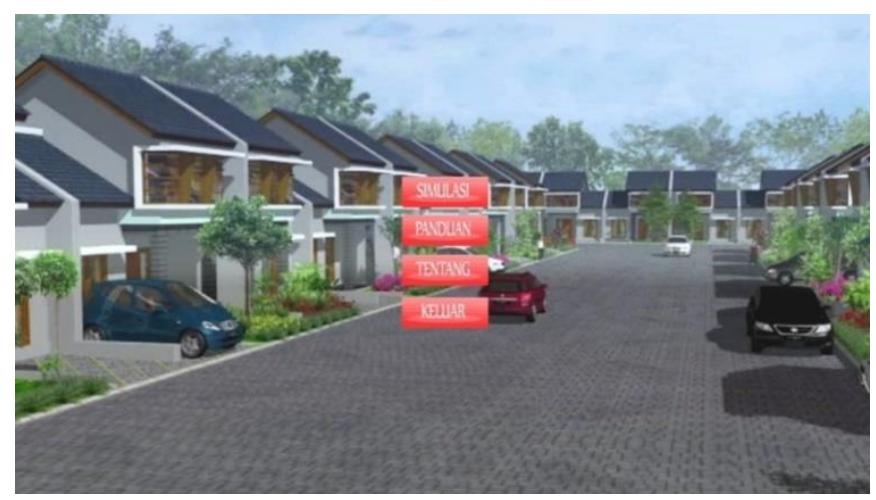

Gambar 8 Tampilan Menu Utama Aplikasi
Pada Gambar 8 merupakan tampilan menu utama adalah sebuah tampilan yang mempunyai beberapa tombol diantaranya tombol simulasi, paduan, tentang dan keluar dimana dari masing-masing tombol tersebut mempunyai fungsi tersendiri diantara lain :

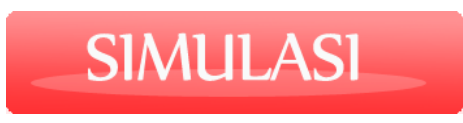

Gambar 9 Tombol Simulasi

Pada Gambar 9 merupakan tombol menuju kamera aplikasi rumah, dimana pengguna dapat melakukan perubahan warna rumah secara dinamis dan membuka atap rumah untuk melihat detail ruangan.

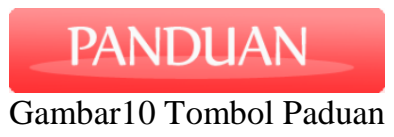

Pada Gambar 10 merupakan tombol menuju paudan aplikasi, dimana pengguna dapat melihat urutan cara menjalankan aplikasi dengan benar.

\section{TENTANG \\ Gambar 11 Tombol Tentang}

Pada Gambar 11 merupakan tombol tentang dimana tombol tersebut menuju informasi mengenai aplikasi.

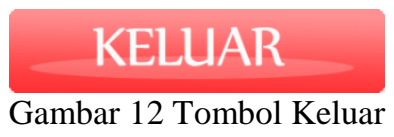

Pada Gambar 12 merupakan tombol keluar aplikasi dimana tombol tersebut menuju keluar aplikasi secara total.

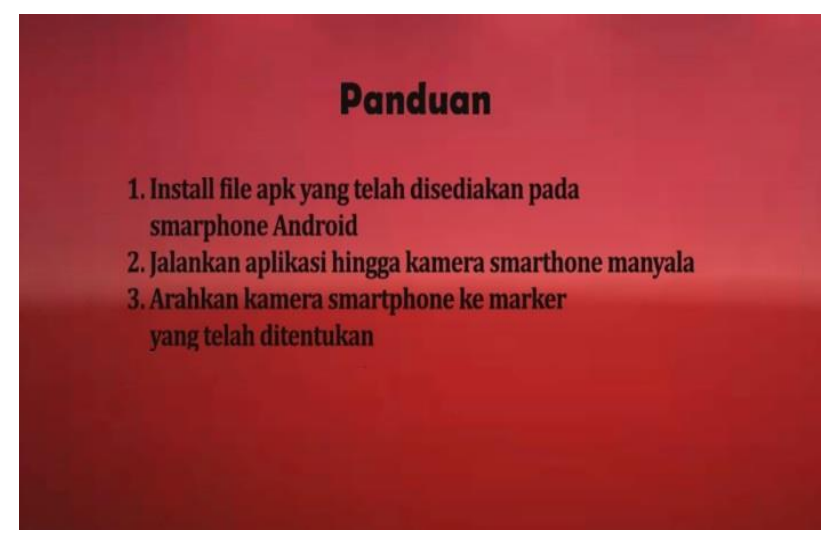

Gambar 13 Tampilan Panduan

Pada Gambar 13 merupakan tampilan Panduan, yang menjelaskan cara-cara penggunaan aplikasi ini. 


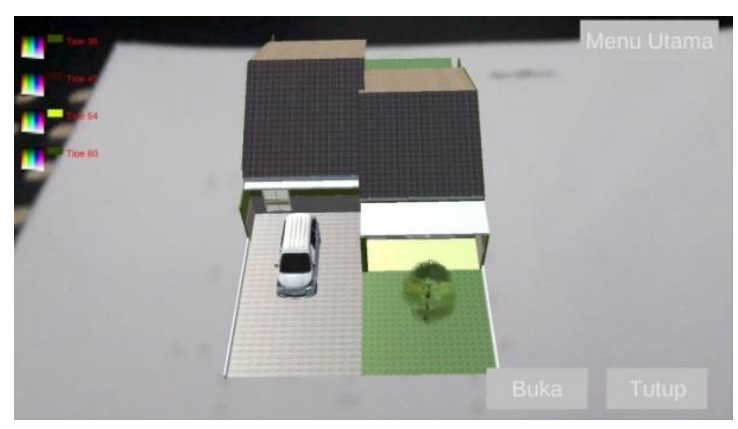

Gambar 14 Tampilan Rumah Tipe 36

Pada Gambar 14 merupakan tampilan rumah dengan tipe 36 berwarna hijau tua, yang dimana pengguna memilih warna hijau tua, maka dinding rumah akan berwarna hijau tua.

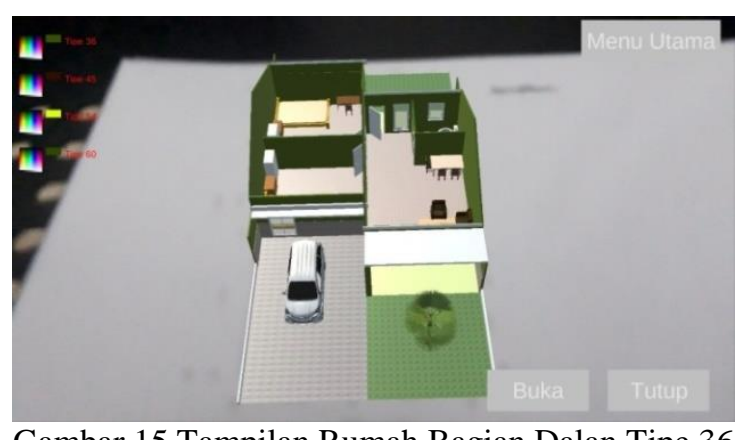

Gambar 15 Tampilan Rumah Bagian Dalan Tipe 36

Pada Gambar 15 merupakan tampilan ruangan rumah tipe 36 secara detail, yang dimana pengguna memilih membuka atap rumah, maka rumah akan terlihat dengan jelas ruangan yang ada didalam rumah.

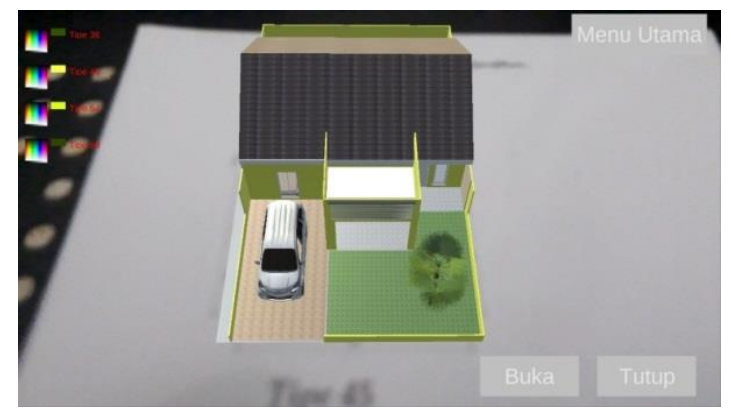

Gambar16 Tampilan Rumah Tipe 45

Pada Gambar 16 merupakan tampilan rumah dengan tipe 45 berwarna hijau muda, yang dimana pengguna memilih warna hijau muda, maka dinding rumah akan berwarna hijau muda.

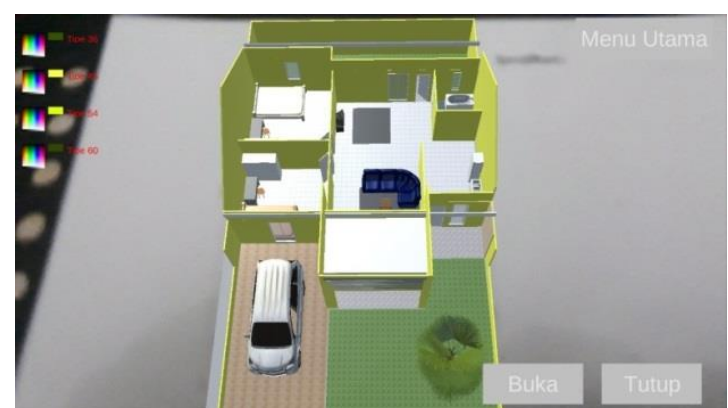

Gambar 17 Tampilan Rumah Bagian Dalam Tipe 45

Pada Gambar17 merupakan tampilan ruangan rumah tipe 45 secara detail, yang dimana pengguna memilih membuka atap rumah, maka rumah akan terlihat dengan jelas ruangan yang ada di dalam rumah.

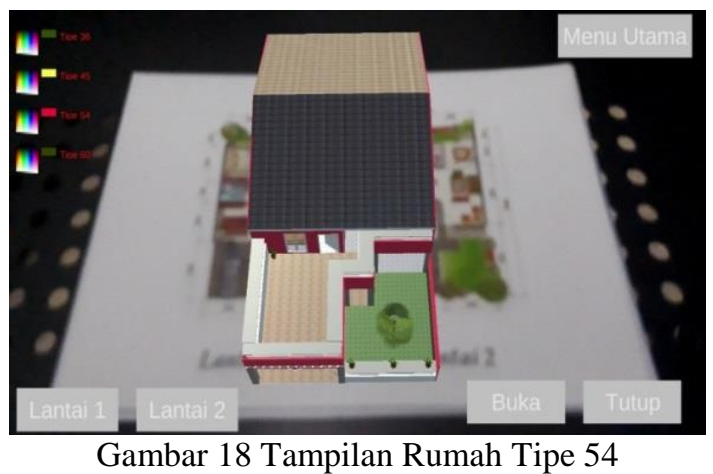

Pada Gambar 18 merupakan tampilan rumah dengan tipe 54 berwarna merah, yang dimana pengguna memilih warna merah, maka dinding rumah akan berwarna merah.

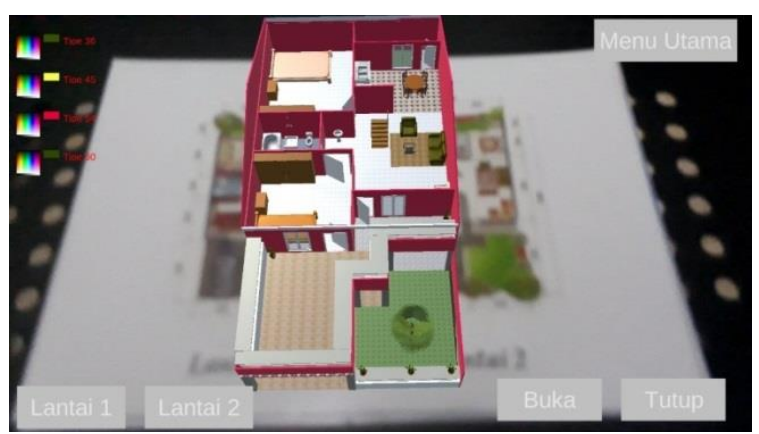

Gambar 19 Tampilan Rumah Tipe 54 Lantai 2

Pada Gambar 19 merupakan tampilan ruangan lantai 2 pada rumah tipe 54, yang dimana pengguna memilih membuka lantai 2 , maka detail ruangan lantai 2 pada rumah akan terlihat. 


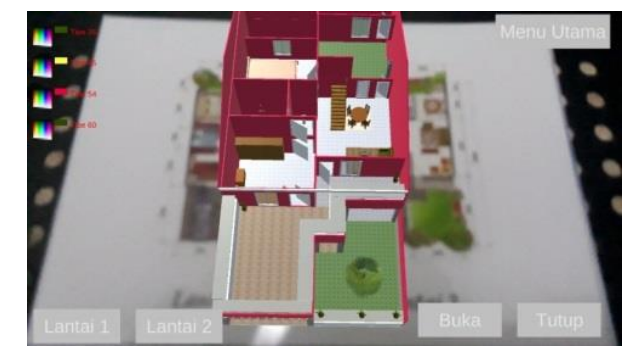

Gambar 20 Tampilan Rumah Tipe 54 Lantai 1

Pada Gambar 20 merupakan tampilan ruangan lantai 1 pada rumah tipe 54, yang dimana pengguna memilih membuka lantai 1 , maka detail ruangan lantai 1 pada rumah akan terlihat.

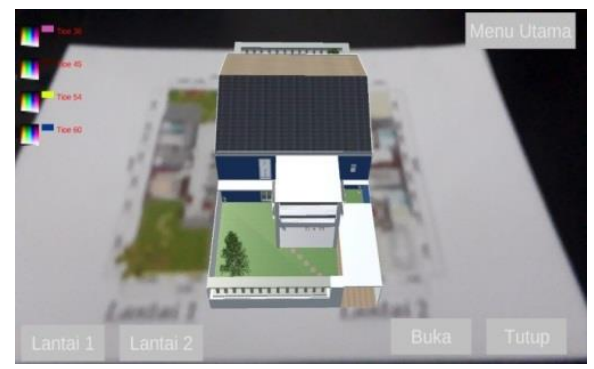

Gambar 21 Tampilan Rumah Tipe 60

Pada Gambar 21 merupakan tampilan rumah dengan tipe 60 berwarna biru, yang dimana pengguna memilih warna biru, maka dinding rumah akan berwarna biru.

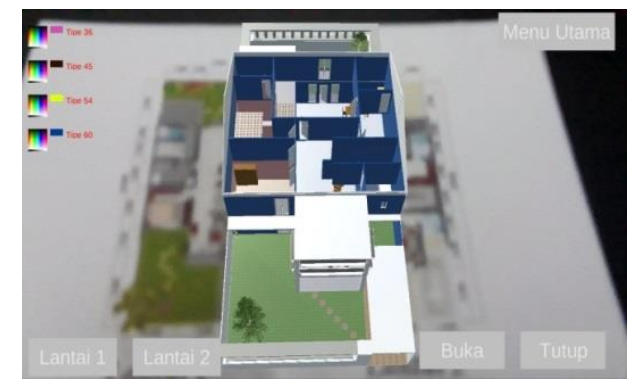

Gambar 22 Tampilan Rumah Tipe 60 Lantai 1

Pada Gambar 22 merupakan tampilan ruangan lantai 1 pada rumah tipe 60 , yang dimana pengguna memilih membuka lantai 1 , maka detail ruangan lantai 1 pada rumah akan terlihat

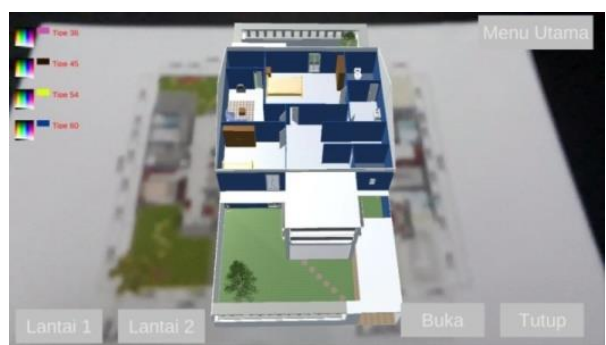

Gambar 23 Tampilan Rumah Tipe 60 Lantai 2
Pada Gambar 23 merupakan tampilan ruangan lantai 2 pada rumah tipe 60 , yang dimana pengguna memilih membuka lantai 2, maka detail ruangan lantai 2 pada rumah akan terlihat. Bahwa desain objek 3 dimensi sudah sesuai dengan barang nyata, terbukti dari penilaian 18 responden atau 90\% memilih sangat baik. Dengan demikian pembuatan aplikasi android yang bertemakan Augmented reality Untuk Media Promosi Rumah pada PT. Alang-alang Construction berbasis android telah selesai dibuat dan telah sesuai dengan rancangan.

Tabel 1 Uji Penerimaan

\begin{tabular}{|c|l|l|l|}
\hline Pertanyaan & Keterangan & Responden & $\begin{array}{c}\text { Persentase } \\
(\%)\end{array}$ \\
\hline $\begin{array}{l}\text { Bagaimana } \\
\text { penilaian } \\
\text { anda } \\
\text { terhadap } \\
\text { keseluruhan } \\
\text { aplikasi ini }\end{array}$ & Sangat Baik & 11 & $55 \%$ \\
\cline { 2 - 4 } & Baik & 8 & $40 \%$ \\
\cline { 2 - 4 } & Kurang & 1 & $5 \%$ \\
\hline \multirow{2}{20}{} & \multicolumn{3}{|c|}{$\mathbf{1 0 0 \%}$} \\
\hline
\end{tabular}

Hasil prosentase pada Tabel 1 maka dapat disimpulkan sebanyak 11 responden atau 55\% menyatakan "Sangat Baik", 8 responden atau $40 \%$ menyatakan "Baik" dan 1 responden atau 5\% menyatakan "Cukup".

\section{KESIMPULAN DAN SARAN}

Berdasarkan hasil pengujian dan analis yang telah dibahas pada bab sebelumnya, maka aplikasi augmented reality pada promosi rumah dapat membantu marketing untuk mempromosikan produknya dan dapat menarik minat klien, terbukti dari penilaian 11 responden atau $85 \%$ memilih sangat baik. Sedangkan dari hasil pengujian program Augmented Reality untuk media promosi rumah terlihat fitur yang disediakan berjalan baik. Saat menampilkan tampilan rumah tipe 36, 54 dan 60 menunjukan kinerja baik dan tampilan terlihat jelas. Untuk pengembangan program promosi rumah berbasi augmented reality perlu ditambahkan sensor, sehingga hasil interaksi yang dihasilkan akan lebih maksimal.

\section{DAFTAR PUSTAKA}

[1] I. V. Reality, "No Title," pp. 165-166, 2013.

[2] T. Blum, "mirracle: An Augmented Reality Magic Mirror System for Anatomy Education," pp. 115-116, 2012.

[3] F. Pankratz, "User Awareness of Tracking Uncertainties in AR Navigation Scenarios," no. 
October, pp. 285-286, 2013.

[4] I. I. Symposium, A. Reality, and A. Proceedings, "2017 IEEE International Symposium on Mixed and Augmented Reality Adjunct Proceedings," pp. 39-41, 2017.

[5] S. Chang and W. Chen, "Does visualize industries matter? A Technology Foresight of Global Virtual Reality And Augmented Reality Industry," pp. 382 385, 2017. 
